\title{
Seroprevalence of leptospirosis in various categories of dogs in Bosnia and Herzegovina
}

\author{
Renata Lindtner Knific ${ }^{1}$, Amel Ćutuk ${ }^{2}$, Gordana Gregurić Gračner ${ }^{3}$, \\ and Alenka Dovč ${ }^{1 *}$ \\ IInstitute for Poultry, Birds, Small Mammals and Reptiles, Veterinary Faculty, University of Ljubljana, \\ Ljubljana, Republic of Slovenia \\ ${ }^{2}$ Department of Ambulatory Service, Veterinary Faculty, University of Sarajevo, Sarajevo, Bosnia and \\ Herzegovina \\ ${ }^{3}$ Department of Animal Hygiene, Behaviour and Welfare, Faculty of Veterinary Medicine, University of \\ Zagreb, Zagreb, Republic of Croatia
}

\section{LINDTNER KNIFIC, R., A. ĆUTUK, G. GREGURIĆ GRAČNER, A. DOVČ: Seroprevalence of leptospirosis in various categories of dogs in Bosnia and Herzegovina. Vet. arhiv 89, 627-640, 2019.}

\section{ABSTRACT}

The increasing number of stray dogs and the lack of sufficient data on the prevalence of leptospirosis among dogs were the main reasons for conducting this research in different populations of dogs on the territory of Bosnia and Herzegovina. A total of 300 serum samples were tested from three different categories of dogs of various breeds from 12 cities. Twelve leptospiral serovars were used in the microscopic agglutination test (MAT). The presence of specific antibodies was confirmed for eight serovars. The proportion of seropositive dogs was $22.3 \%(67 / 300)$. The highest seropositivity $(n=38 ; 42.7 \%)$ was found for the serovar Pomona. The seropositivity rates found for the other serovars tested were as follow: Canicola (14.6\%), Icterohaemorrhagiae (13.5\%), Sejroe (12.4\%), Autumnalis (12.4\%), Grippotyphosa (2.2\%), Bratislava (1.1\%), and Australis (1.1\%). The highest number of positive responses was obtained at the serum dilution of $1: 100(39.3 \%, \mathrm{n}=35)$. The highest number of positive reactions was identified in the category of 'house dogs' $(29.3 \%, 29 / 99)$ followed by 'stray dogs' $(21.6 \%, 24 / 111)$, while the lowest number of positive tests was recorded in the category of 'guard/ hunting dogs' $(15.6 \%, 14 / 90)$. Vaccination with tetravalent vaccines, including the serovars Icterohaemorrhagiae, Canicola, Pomona and Grippotyphosa could be an effective measure for the prevention of canine leptospirosis.

Key words: leptospirosis; diagnostics; microscopic agglutination test; serology; dogs; Bosnia and Herzegovina

\footnotetext{
*Corresponding author:

Prof. dr. Alenka Dovč, DVM, PhD, University of Ljubljana, Veterinary Faculty, Institute for Poultry, birds, Small Mammals and Reptiles, Gerbičeva 60, 1000 Ljubljana, Slovenia, Phone: +386 1477 925; Fax: +386 1477 9339; E-mail: alenka.dovc@vf.uni-lj.si
} 


\section{Introduction}

Recently leptospirosis has become a 're-emerging disease' of epidemic appearance in the urban areas of large cities in developing countries, where the disease affects human residents and animals alike. This is due to the sudden build-up of rodents and risk groups of animals in cities and the rapid expansion of the cities' periphery with poor environmental sanitation and slow development of adequate infrastructure. Unsanitary living conditions, overcrowding, mushrooming rat populations, and often natural disasters such as hurricanes and heavy rains with floods, contribute to the epidemic spread of leptospirosis (KO et al., 1999).

Bosnia and Herzegovina $(\mathrm{BH})$ is a country in transition moving towards joining the European Union. In the $\mathrm{BH}$ region, the presence of leptospirosis has been studied in cattle, pigs, sheep and dogs on a limited scale, and for many areas of this country there are no data in terms of the territorial distribution, the extent of the affected animals, and the serotypical association of leptospires that cause infections in animals. Comparison has been conducted with the results of similar surveys in countries in the region in which leptospirosis is a public health problem. The events of the war certainly affected the situation and the movement of many contagious animal diseases in the epidemiological area of BH. Numerous unfavourable factors from that time, as well as those that occurred in the post-war period, have contributed to the change in the epizootiological situation of leptospirosis in the country (ĆUTUK, 2015).

Canine leptospirosis is a septicemic contagious disease of panzootic scale, caused by various pathogenic serovars of the genus Leptospira, which are Gram-negative, aerobic bacteria. The disease is widespread throughout the world with the exception of the Antarctic, with growing frequency, from subpolar to subtropical and tropical areas with a warm and humid climate that allows the bacteria to survive (SYKES et al., 2011). It is most widespread in lowland areas along rivers, lakes and ponds, and is considered to be one of the most widespread zoonoses in the world (BHARTI et. al, 2003).

The dog is the primary host for serovar Canicola, which also occurs in rats, raccoons, hedgehogs, voles and ferrets, However, dogs can become infected with several other serovars (Icterohaemorrhagiae, Pomona, Sejroe, Autumnalis, Grippotyphosa, Bratislava, Australis, Bataviae, etc.), for which dogs are regarded as secondary or accidental hosts (RIBOTTA et al., 2000). Earlier studies on the presence of leptospirosis in dogs showed that in urban environments the disease is often caused by the serovars Canicola and Icterohaemorrhagiae, while in suburban and rural locations Pomona and Grippotyphosa are identified as the dominant serovars (KAHN and LINE, 2005).

Infection among dogs is usually spread by them sniffing each other's genital organs and places contaminated with the urine of infected dogs (BROWN et al., 1996), by coitus and by contact with rodents (primarily rats acting as the main source and reservoir 
of Leptospira in urban areas), or with infected domestic and wild animals. There are also records suggesting that infection in dogs occurred after drinking, or swimming in, contaminated water (MOORE et al., 2006). The incubation period in dogs lasts 7-20 days (BROWN et al., 1996) depending on the dose and strain of the pathogen and the host (SYKES et al., 2011).

GEISEN et al., 2007 mentioned that most common clinical signs included lethargy, anorexia, vomiting, weakness, diarrhoea and weight loss. Physical examination abnormalities included icterus, dehydration, red to brownish coloured urine, abdominal pain, fever and hypothermia.

The acute form may present with fever with a body temperature up to $41^{\circ} \mathrm{C}$, apathy, weakness, bloody diarrhoea, and numerous mucosal bleedings (BROWN et al., 1996). Fever occurs early in the course of illness, and may be accompanied by shivering, generalized muscle tenderness, and reluctance to move. Dogs presenting with acute renal failure may show polyuria, polydipsia, dehydration, vomiting, diarrhoea, inappetence, lethargy, or abdominal pain, or some combination of these signs. Oliguria or anuria also may occur. Dogs may present with signs of hepatic failure, including icterus. Other reported manifestations of infection include conjunctivitis, uveitis, and tachypnea or dyspnoea because of acute respiratory distress syndrome or leptospiral pulmonary haemorrhage syndrome (LPHS), which has been reported most frequently in dogs from some parts of Europe (SYKES et al., 2011). The subacute form is the most frequently diagnosed, and the clinical signs include fever, anorexia, vomiting, dehydration, lethargy, muscle pain, diarrhoea, compromised agglutination due to liver involvement or vasculitis that may lead to petechiae and/or ecchymoses, and polyuria and polydipsia can appear (VAN DE MAELE et al., 2008). The chronic form is associated with interstitial nephritis or active hepatitis, loss of body mass, ascites, and signs of hepatic encephalopathy. Animals with or without visible clinical signs present a particularly high epizootiological risk, as they are the reservoirs and long-term carriers of the bacteria in nature (RADOJIČIĆ et al., 2011).

The aim of this survey was to determine the prevalence of leptospirosis in dogs in Bosnia and Herzegovina (BH). The investigation was justified by the fact that $\mathrm{BH}$ is a country in transition that strives to join the European Union (EU). The implementation of measures for the regular monitoring, prevention and control of communicable diseases, particularly zoonoses, is one of the basic prerequisites for membership in the EU. Another objective was to compare the findings with the results of similar surveys in the neighbouring countries.

\section{Materials and methods}

All studies were conducted at the Department of Infectious Animal Diseases and Epizootiology and the Department of Internal Animal Medicine at the Veterinary Faculty in Sarajevo, the 'Stup' Veterinary Station in Sarajevo, as well as at the Laboratory for 
Leptospirosis at the Institute for Poultry, Birds, Small Mammals and Reptiles of the Veterinary Faculty, University of Ljubljana, Slovenia.

Materials. The study included a total of 300 dogs (201 males and 99 females) of different breeds, originating from 12 cities: Busovača, Goražde, Jablanica, Ključ, Konjic, Lukavac, Prijedor, Sanski Most, Sarajevo, Travnik, Tuzla, and Zenica. The age of the dogs tested ranged from 6 months to 10 years. The dogs were divided into three categories: pet dogs ('house dogs', $\mathrm{n}=99$ ), abandoned dogs ('stray dogs', $\mathrm{n}=111$ ), and dogs that are in constant contact with other animals on cattle or sheep farms ('guard/hunting dogs', $n$ $=90)$.

Before taking samples of blood every dog was examined clinically. The recorded signs of disease or infection were: general infectious syndrome, anaemia (complete haematological tests were performed), jaundice of the visible mucous membranes, muscular pain, coughing, vomiting, and clinical changes of the urinary system. During sampling, the provisions of the Animal Protection and Welfare Act (Official Gazette 316/09) were complied with, and the dog owners' oral and written consent was obtained.

Data about vaccination status were recorded with respect to standard vaccinations with Leptospira antigens included (Icterohaemorrhagiae and Canicola). Information about the vaccines used was needed for the subsequent interpretation of serological reactions when determining post-vaccinal antibody titres Dogs that were not vaccinated regularly, as well as those last immunized more than one year before sampling, were regarded as unvaccinated.

Methods. A total of 300 samples were tested using the microscopic agglutination test (MAT). From all dogs, $2 \mathrm{~mL}$ blood samples were taken by puncture of the vena cephalica antebrachii. Vacutainers containing gel were used for the biochemical measurements. Twelve Leptospira serovars were used in the MAT. Four- to eight-day-old live cultures of the serovars Grippotyphosa, Canicola, Sejroe, Pomona, Tarassovi, Icterohaemorrhagiae, Australis, Autumnalis, Bratislava, Bataviae, Saxkoebing, and Hardjo bovis were used for routine testing.

All raw data were first entered in the MS Excel spread sheet program and then modified and transferred to the corresponding tables of the SPSS v.20.0 statistical program for statistical analysis, in accordance with the established objectives. The basic descriptive statistics of the questionnaire and the results of the MAT for the detection of specific antibodies were analysed. The chi-square test $(\chi 2)$ was used to determine differences in the presence of antibodies to the different serovars in each of the three categories of dogs tested.

\section{Results}

Most of the dogs examined were in good condition. General clinical examination revealed clinical signs related to eye and/or nasal discharge in $17.3 \%(52 / 300)$, respiratory 
problems in 5.8\%, digestive problems in $15.4 \%$, reproductive disturbances in $3.9 \%$ and urinary tract disorders in $19.2 \%$ of the dogs, while $26.9 \%$ of the dogs showed other health problems.

The seroprevalence was found to be $22.3 \%$ (67/300) considering a serum dilution of 1:100 or more as positive. The highest number of seropositive dogs was detected in the category of 'house dogs' $(29.3 \%, 29 / 99)$ followed by the category of 'stray dogs' $(21.6 \%$, $24 / 111$ ), while the lowest number of seropositive dogs was recorded in the category of 'guard/hunting dogs' $(15.6 \%, 14 / 90)$. Out of the 67 seropositive dogs, $46(68.7 \%)$ had antibodies against one serovar, $20(29.8 \%)$ against two serovars, and only one dog $(1.5 \%)$ had antibodies against three serovars. The differences in the number of seronegative and seropositive dogs were not statistically significant between the various dog categories $\left(\mathrm{Chi}^{2}=5.180, \mathrm{df}=2, \mathrm{P}=0.075\right)$, even though the percentage difference between the categories of 'house dogs' and 'guard/hunting dogs' was almost $14 \%$.

Seroprevalence

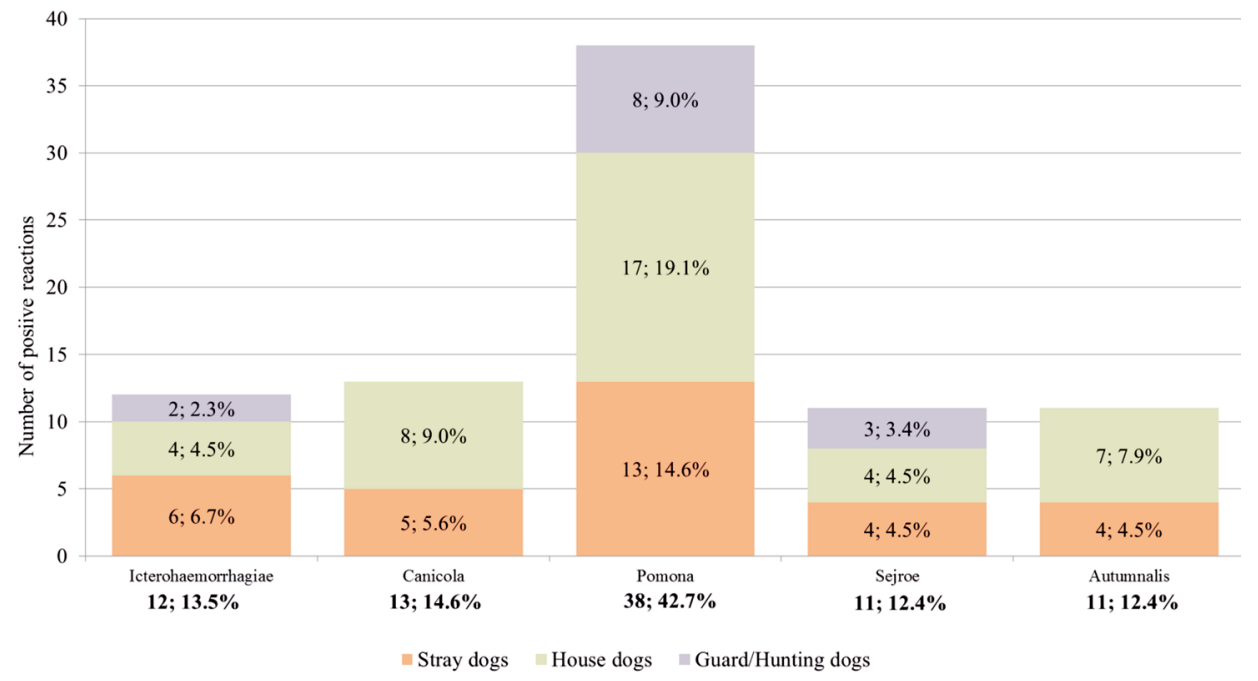

Fig. 1. Positive reactions to individual serovars $(n=85 ; 95.6 \%)$ detected in different categories of dogs (total $\mathrm{n}=89 ; 100.0 \%)$. Serovars Grippotyphosa $(2 ; 2.2 \%)$, Bratislava $(1 ; 1.1 \%)$ and Australis $(1 ; 1.1 \%)$ are not included.

Fig. 1. presents the positive results obtained in the different categories of dogs and the subtyping of serovars are presented. The highest seroprevalence was found for Pomona, with $38(42.7 \%)$ positive dogs, followed by Canicola with $12(13.5 \%)$ and Icterohaemorrhagiae with $13(14.6 \%)$ positive dogs. Antibodies to Sejroe and Autumnalis were detected in $11(12.4 \%)$ dogs, while those to Grippotyphosa were demonstrated in 
two dogs (2.2\%). The lowest seroprevalence was found for Bratislava and Australis, with one seropositive dog each (1.1\%). Differences in the prevalence of antibodies to Icterohaemorrhagiae among the three categories of dogs were not statistically significant $\left(\mathrm{Chi}^{2}=1.240, \mathrm{df}=2, \mathrm{P}=0.538\right)$. Likewise, no statistically significant differences were obtained for Pomona $\left(\mathrm{Chi}^{2}=0.107, \mathrm{df}=2, \mathrm{P}=0.948\right)$ and Sejroe $\left(\mathrm{Chi}^{2}=0.392, \mathrm{df}=2, \mathrm{P}\right.$ $=0.822$ ) among the dog categories tested. Statistically significant differences among the three categories of dogs were found for Canicola $\left(\mathrm{Chi}^{2}=7.204, \mathrm{df}=2, \mathrm{P}=0.027\right)$ and Autumnalis $\left(\mathrm{Chi}^{2}=6.154, \mathrm{df}=2, \mathrm{P}=0.046\right)$. None of the dogs reacted positive against serovars Tarassovi, Bataviae, Saxkoebing and Hardjo.

Table 1. Antibody titres to individual serovars detected in different categories of dogs

\begin{tabular}{|l|c|c|c|c|c|c|}
\hline Serovars/Antibody titres & $1: 50$ & $1: 100$ & $1: 200$ & $1: 400$ & $1: 800$ & TOTAL \\
\hline sv. Icterohaemorrhagiae & $2(2.2)$ & $8(9.0)$ & $2(2.2)$ & $0(0.0)$ & $0(0.0)$ & $12(13.5)$ \\
\hline Guard/Hunting dogs & 1 & 1 & 0 & 0 & 0 & $2(2.3)$ \\
\hline House dogs & 0 & 3 & 1 & 0 & 0 & $4(4.5)$ \\
\hline Stray dogs & 1 & 4 & 1 & 0 & 0 & $6(6.7)$ \\
\hline sv. Canicola & $5(5.7)$ & $7(7.9)$ & $0(0.0)$ & $1(1.1)$ & $0(0.0)$ & $13(14.6)$ \\
\hline House dogs & 3 & 4 & 0 & 1 & 0 & $8(9.0)$ \\
\hline Stray dogs & 2 & 3 & 0 & 0 & 0 & $5(5.6)$ \\
\hline sv. Pomona & $5(5.7)$ & $12(13.5)$ & $14(15.8)$ & $5(5.7)$ & $2(2.2)$ & $38(42.7)$ \\
\hline Guard/Hunting dogs & 2 & 2 & 3 & 1 & 0 & $8(9.0)$ \\
\hline House dogs & 0 & 4 & 8 & 3 & 2 & $17(19.1)$ \\
\hline Stray dogs & 3 & 6 & 3 & 1 & 0 & $13(14.6)$ \\
\hline sv. Sejroe & $5(5.7)$ & $2(2.2)$ & $3(3.4)$ & $1(1.1)$ & $0(0.0)$ & $11(12.4)$ \\
\hline Guard/Hunting dogs & 1 & 0 & 2 & 0 & 0 & $3(3.4)$ \\
\hline House dogs & 2 & 0 & 1 & 1 & 0 & $4(4.5)$ \\
\hline Stray dogs & 2 & 2 & 0 & 0 & 0 & $4(4.5)$ \\
\hline sv. Bratislava & $1(1.1)$ & $0(0.0)$ & $0(0.0)$ & $0(0.0)$ & $0(0.0)$ & $1(1.1)$ \\
\hline Guard/Hunting dogs & 1 & 0 & 0 & 0 & 0 & $1(1.1)$ \\
\hline sv. Grippotyphosa & $2(2.2)$ & $0(0.0)$ & $0(0.0)$ & $0(0.0)$ & $0(0.0)$ & $2(2.2)$ \\
\hline House dogs & 1 & 0 & 0 & 0 & 0 & $1(1.1)$ \\
\hline Stray dogs & 1 & 0 & 0 & 0 & 0 & $1(1.1)$ \\
\hline sv. Australis & $1(1.1)$ & $0(0.0)$ & $0(0.0)$ & $0(0.0)$ & $0(0.0)$ & $1(1.1)$ \\
\hline House dogs & 1 & 0 & 0 & 0 & 0 & $1(1.1)$ \\
\hline sv. Autumnalis & $2(2.2)$ & $6(6.7)$ & $2(2.2)$ & $1(1.1)$ & $0(0.0)$ & $11(12.4)$ \\
\hline House dogs & 1 & 4 & 1 & 1 & 0 & $7(7.9)$ \\
\hline Stray dogs & 1 & 2 & 1 & 0 & 0 & $4(4.5)$ \\
\hline TOTAL & $23(25.9)$ & $35(39.3)$ & $21(23.6)$ & $8(9.0)$ & $2(2.2)$ & $89(100.0)$ \\
\hline
\end{tabular}


Table 1 shows the antibody titres demonstrated to different serovars in the three categories of dogs. Eleven out of the 29 seropositive 'house dogs' $(n=42)$ had antibodies to two different serovars and one dog was seropositive for three different serovars. In house dogs, Pomona had the highest seroprevalence $19.1 \%$, followed by Canicola in $9.0 \%$, Autumnalis in $7.9 \%$ ), Icterohaemorrhagiae and Sejroe in $4.5 \%$, while in $1.1 \%$ of the house dogs a positive reaction was found to Grippotyphosa and Australis. In this category of dogs there were no positive reactions to Bratislava. Antibodies against Pomona in a final dilution of 1:800 were found in two dogs. Most of the dogs (96.9\%) had been vaccinated. In nine out of the 24 seropositive 'stray dogs' $(\mathrm{n}=33)$ simultaneous infection with two serovars was detected. Seropositivity to Pomona was found in 13 (39.4\%) dogs, followed by Icterohaemorrhagiae in $6(18.2 \%)$, Canicola in $5(15.2 \%)$, Sejroe and Autumnalis in $4(12.1 \%)$ and to Grippotyphosa in only one $\operatorname{dog}(3.0 \%)$. The highest antibody titre (1: 400 ) was found to Pomona in one case. Of the total number of dogs in this group ( $\mathrm{n}=$ $24), 16(66.6 \%)$ had been vaccinated and $8(33.3 \%)$ had not been vaccinated. All of the 14 seropositive 'guard/hunting dogs' were positive to only one of the serovars tested (n =14). Positive reactions were mostly found for Pomona in 8 dogs, $(57.1 \%)$, followed by Sejroe in $3(21.4 \%)$, Icterohaemorrhagiae in two (14.3\%) and Bratislava in one $(7.1 \%)$ dog. In this category of dogs, no seropositivity was detected for the other four serovars used in the MAT. The highest antibody titre (1:400) was demonstrated against Pomona in one dog. All dogs in this category had been vaccinated (100.0\%).

Antibody titres of 1:200 were found in 14 dogs, 1:100 in 12 dogs, 1:50 and 1:400 in five dogs each, and 1:800 in two dogs. The highest antibody level of 1:800 was found against Pomona in two samples. The highest antibody titre detected against the serovars Canicola and Sejroe was 1:400. Most of the serovars $(n=35)$ induced antibody titres of 1:100, while antibody titres demonstrated against Bratislava and Australis were not higher than 1:50. Antibody titres found for Canicola and Icterohaemorrhagiae may indicate that the dogs had been vaccinated. According to the vaccination history of all dogs surveyed $(\mathrm{n}=300), 79.3 \%(238 / 300)$ had been vaccinated with one of the commercial bivalent vaccines. Fifty-eight out of the 238 vaccinated dogs (24.4\%) had specific antibody titres against the tested serovars, but antibodies were due to vaccinal antigens in only $8.0 \%$ of the vaccinated dogs $(19 / 238)$.

\section{Discussion}

Before this study, the presence of leptospirosis in animals had been explored only to a limited extent on the territory of $\mathrm{BH}$, and in many areas of the country there are no data on territorial prevalence, the proportion of dogs affected and identification of the Leptospira serovars present. 
According to the Anadolu Agency, the omnipresent problem of stray dogs is one of the most complex issues for citizens, non-governmental organizations and institutions in $\mathrm{BH}$. Although there are no official data on how many dogs are wandering the streets, the estimated number is about 50,000. It is assumed that in the territory of the Sarajevo canton alone about 13,000 dogs roam free. Stray dogs pose a major problem and a serious threat to public health because many of the abandoned dogs are potential carriers of infectious diseases that can endanger the health of other animals and people. It is also an alarming fact that today a large number of owned dogs, regardless of whether they are kept indoors or in the backyard, are not monitored regularly for zoonotic diseases.

The most comprehensive study of leptospirosis in dogs in the territory of Sarajevo (but not in the whole territory of BH) was conducted in 1992 by OŽEGOVIĆ. Then $67.5 \%$ of the surveyed dogs were seropositive, while in our study, conducted 25 years later, $22.3 \%$ of the dogs tested had specific antibodies against Leptospira. Of all dogs tested, $79.3 \%$ had been vaccinated at least one year before sampling. Positive reactions for Canicola were identified in $14.6 \%$ and for Icterohaemorrhagiae in $13.5 \%$ of the dogs. The prevalence of vaccinal serovars was lower than expected, but the presence of such serovars is not an absolutely reliable indicator of immunological protection against leptospirosis. KLAASEN et al. (2003) reported that immunization prevents only the highly expressed clinical signs of the disease but does not protect animals from infection. Adequate immunization consists of at least two vaccinations in intervals of two to three weeks, and immunity usually lasts for six to eight months, which is very important for restoration of immunity, especially in dogs coming into contact with swamps and muddy areas, and also in hunting and rescue dogs. Scientists are of the opinion that, unlike viral vaccines, bacterial vaccines do not induce immunity that reliably lasts 12 months or more, so they suggest that vaccination should be repeated at shorter intervals than viral vaccines.

It has been found that bacterin-derived vaccines (i.e., vaccines created to immunize against bacterial diseases) against leptospirosis and other diseases (for example, kennel cough and Lyme disease) probably do not even provide protective immunity for a full 12 months. Without more frequent vaccinations, this may lead to outbreaks of these diseases (DAVOL, 2001).

In the past the most common disease-causing serovars were Icterohaemorrhagiae and Canicola, but from the early 1970s the use of vaccines containing these two serovars significantly reduced their prevalence. Recently there has been an increase in the number of infected dogs in Europe, partly due to changes in the prevalence of infectious serovars that are not included in the vaccines (ŠTRITOF-MAJETIĆ et al., 2012). In Europe the most commonly used inactivated vaccines contained the serovars Canicola and Icterohaemorrhagiae (ANDRE-FONTAINE, 2006), while in North America vaccines with four attenuated serovars, Icterohaemorrhagiae, Canicola, Pomona, and Grippotyphosa are 
used (CLAUS et al., 2008). In the last decade tetravalent vaccines are produced with different combinations of Icterohaemorrhagiae, Canicola, Grippotyphosa, Bratislava, Pomona and/or Sejroe.

While the pathogenesis of leptospirosis is well documented at the level of the whole animal, the cellular and molecular basis remains obscure. Killed, whole-cell bacterin vaccines are licensed worldwide and have not changed substantially over the past several decades. Vaccine-induced immunity is restricted to serologically related serovars and is generally short-lived, necessitating annual revaccination. The appearance of new serovars, as causes of canine leptospirosis, requires constant epidemiological surveillance and tailoring of vaccines to cover emerging serovars. At the present time, there is no realistic prospect of alternative, non-bacterin vaccines becoming available in the foreseeable future (KLAASEN and ALDER, 2015).

The data obtained in this survey suggest that vaccination with a bivalent vaccine as a preventive measure to protect dogs against leptospirosis in $\mathrm{BH}$ did not produce satisfactory results, although revaccination had been performed at regular intervals. The high percentage of seropositivity for Pomona shows that other measures of specific and nonspecific disease prophylaxis should be implemented to suppress the spread of the disease among new populations of dogs. Our results indicate that vaccination with tetravalent vaccines, including Icterohaemorrhagiae, Canicola, Pomona and Grippotyphosa, would be one of the effective preventive measures. A similar conclusion was drawn by ELLIS (2010).

In the survey conducted by OŽEGOVIĆ (1992), the highest number of dogs were seropositive for Canicola and Icterohaemorrhagiae (12.0\%). The prevalence of other serovars in the seropositive dogs was as follows: Grippotyphosa $11.5 \%$, Bataviae 10.6\%, Ballum 9.5\%, Hardjo 8.6\%, Tarassovi (strain Mitis Johnson) 8.6\%, Sejroe 7.9\%, Pomona $7.2 \%$, Australis $7.1 \%$, and Saxkoebing $6.3 \%$. In our study, 67 out of the 300 dogs tested were seropositive $(22.3 \%)$, and the highest seroprevalence was found for Pomona $(42.7 \%)$. The prevalences of the other identified serovars were as follow: Canicola $14.6 \%$, Icterohaemorrhagiae $13.5 \%$, Sejroe $12.4 \%$, Autumnalis $12.4 \%$, Grippotyphosa $2.2 \%$, Bratislava $1.1 \%$, and Australis $1.1 \%$. Antibodies to one serovar were found in $68.7 \%$, while antibodies to two serovars were detected in $29.8 \%$ of the seropositive dogs. Antibodies against three different serovars (Canicola, Pomona and Grippotyphosa) were found in only one dog. Tests for Tarassovi, Bataviae, Saxkoebing and Hardjo were always negative.

In our survey, Pomona showed the highest seroprevalence: $40.5 \%$ in 'house dogs', $39.4 \%$ in 'stray dogs' and $57.1 \%$ in 'guard/hunting dogs'. It should also be noted that the highest antibody titres (1:400 and 1:800) were also found to Pomona. The high prevalence obtained in the category of 'guard/hunting dogs' can be explained by their close and 
frequent contact with wild and domestic pigs, which were found to be the most common carriers of Pomona. This serovar was found in wild boars in Croatia with a prevalence of $26 \%$ by CVETNIĆ et al., (2003) as well as in Slovenia with a prevalence of $45 \%$ by VENGUŠT et al. (2008).

A recent serological survey of canine leptospirosis in Croatia showed $37.7 \%$ overall seropositivity, with Pomona, Grippotyphosa, Icterohaemorrhagiae, Australis, Saxkoebing and Hardjo being the most frequently detected serovars in dogs with suspected leptospirosis (ŠTRITOF MAJETIĆ et al., 2012). Most of the infections in dogs were caused by serovars not incorporated in commercial vaccines used for immunization. Even though comparison of these results with our findings concerning the percentage of seropositivity is not possible, Pomona was found to be the predominant serovar in both countries and most of the infections in dogs were caused by serovars not incorporated in commercial vaccines used for immunization in Croatia and $\mathrm{BH}$.

Analysing the seropositive population of the dogs tested, the following facts can be established: the proportion of vaccinated dogs among the seropositive animals was $91.9 \%$ (91/99) for 'house dogs', 62.2\% (69/111) for 'stray dogs' and 86.7\% (78/90) for 'guard dogs/hunting dogs'. Considering the proposed regular vaccination, especially among 'house dogs', for the other serovars (except Icterohaemorrhagiae and Canicola) we had expected lower seropositivity than what was actually found. This can be explained by the insufficient preventive measures, including control of the rodent population that acts as the main reservoir of the disease, and by the lack of strict veterinary hygiene regulations. Single MAT titre values are difficult to interpret in a recently vaccinated dog and a concomitant reaction to natural infection is also possible. The MAT is considered the diagnostic test of choice in dogs with suspected leptospirosis. The MAT results can be negative in the beginning of/the first few days of acute infections, and do not differentiate vaccinated from infected dogs, which makes the interpretation of results challenging (SYKES et al., 2011).

OŽEGOVIĆ (1992) found the highest percentages of seropositive dogs in the category of hunting $(73.0 \%)$ and stray dogs $(72.4 \%)$, followed by house dogs $(59.5 \%)$ and police dogs $(55.8 \%)$, and the lowest percentage among watch dogs (41.1\%). In our study $29.3 \%$ of 'house dogs' had specific antibodies to leptospira, followed by the category of 'stray dogs' $(21.6 \%)$, while the lowest proportion of seropositive dogs $(15.6 \%)$ was recorded in the category of 'guard/hunting dogs'.

In a serological survey conducted with different serological tests on 317 samples from stray dogs in the territory of the Republic of Serbia, leptospiral antibodies were detected in $8.5 \%$ of the cases. The most frequent serovars were Icterohaemorrhagiae and Pomona (ELEZOVIĆ et al., 2011). Another study, covering 113 hunting dogs in western Serbia, showed $6.2 \%$ seropositivity with the highest prevalence of Pomona $(2.7 \%)$, 
followed by Canicola, Bataviae, Sejroe and Australis (MARIĆ et al., 2012). In Germany, the seroprevalence of canine leptospirosis was found to be $35 \%$ in 2002, $42 \%$ in 2004 and $29.8 \%$ in 2005 (JANSEN et al., 2005). In Russia 30.6\% of the tested dogs were seropositive (STOYANOVA et al., 2004). High seroprevalence values were demonstrated in Italy $(29.3 \%)$ and Spain (36\%) as well (SCANZIANI et al., 2002). Lower prevalences were reported from Greece (11.4\%; BURRIEL, 2003), France (6.7\%; ANDREFONTAINE, 2006), Austria (6.0\%; DUCHOW, 2009) Switzerland (3.7\%; MAJOR, 2014), and England (1.3\%; FAINE et al., 2000); it should be mentioned, however, that some of these values were obtained using molecular diagnostic methods.

The seroprevalence in randomly sampled groups of privately owned or stray dogs is an indicator of the spread of and exposure to Leptospira spp. bacteria in these dog populations. The variation in seroprevalence in these categories of dogs, even after removing the 'low MAT titres possibly induced by vaccine serovars', appears to be strikingly high: $13-57 \%$ in Europe, 6-38\% in North America, 7-62\% in South and Central America and the Caribbean, 7-46\% in Asia and the South Pacific, and 5-27\% in Africa and the Middle East (KLAASEN and ALDER, 2015). The results obtained in our study ( $22.3 \%$ overall seroprevalence) show good agreement with the average seroprevalence of canine leptospirosis found elsewhere in Europe, but some differences in prevalence of presumptive infective serogroups were noted. Our findings support the need for adding Pomona antigens to vaccines present on the European market.

\section{References}

ANDRE-FONTAINE, G. (2006): Canine leptospirosis - do we have a problem? Vet. Microbiol. $117,19-24$.

DOI: $10.1016 /$ j.vetmic.2006.04.005

BHARTI, A. R., J. E. NALLY, J. N. RICALDI, M. A. MATTHIAS, M. M. DIAZ, M. A. LOVETT, P. N. LEVETT, R. H. GILMAN, M. R. WILLIG, E. GOTUZZO, J. M. VINETZ (2003): Leptospirosis: a zoonotic disease of global importance. Lancet Infect. Dis. 3, 757-771. DOI: 10.1016/S1473-3099(03)00830-2

BROWN, C. A., A. W. ROBERTS, M. A. MILLER, D. A. DAVIS, S. A. BROWN, S. A. BOLIN, J. JARECKI-BLACK, C. E. GREENE, D. MILLER-LIEBL (1996): Leptospira interrogans serovar Grippotyphosa infection in dogs. JAVMA-J. Am. Vet. Med: A. 209, 1265-1267.

BURRIEL, A. R., C. DALLEY, M. J. WOODWARD (2003): Prevalence of leptospira species among farmed and domestic animals in Greece. Vet. Rec. 153, 146-148.

DOI: $10.1136 /$ vr.153.5.146

ClAuS, A., I. VAN DE MAELE, F. PASMANS, K. GOMMEREN, S. DAMINET (2008): Leptospirosis in dogs: a retrospective study of seven clinical cases in Belgium. Vlaams Diergen. Tijds. 77, 259-263. 
CVETNIĆ, Z., J. MARGALETIĆ, J. TONČIĆ, N. TURK, Z. MILAS, S. SPIČIĆ, M. LOJKIĆ, S. TERZIĆ, L. JEMERŠIĆ, A. HUMSKI, M. MITAK, B. HABRUN, B. KRT (2003): A serological survey and isolation of leptospires from small rodents and wild boars in the Republic of Croatia. Vet. Med.-CZECH. 48, 321-329.

ĆUTUK, A. (2015): Leptospirosis and chlamydiosis of different dog populations in the territory of Bosnia and Herzegovina. PhD Thesis, University of Sarajevo, Veterinary Faculty, Sarajevo, Bosnia and Hercegovina (in Bosnian).

DAVOL, P. A. (2001): Canine leptospirosis: Current issues on infection and vaccination. 2001. Available from: http://www.labbies.com/index.html\#HealthandGenetics.

DUCHOW, K. K. HARTMANN, M. HORZINEK, H. LUTZ, R. STRAUBINGER, U. TRUYEN (2009): Guideline for vaccination of small (companion) animals. Deutsches Tierärzteblatt 8, Beilage "Ständige Impfkommission Vet. in Bundesverband Praktizierender Tierärzte e. V. (bpt) 16-17.

ELEZOVIĆ, M., A. SAMOKOVLIJA, D. VOJINOVIĆ, T. JOVANOVIĆ, M. DJURIĆ, J. MARIĆ, B. BOBIĆ GAVRILOVIĆ, V. TERZIN, B. ĐURIČIĆ (2011): Investigation of seroprevalence of antibodies to Leptospira spp. in population of stray dogs in Belgrade area [abstract]. In: $17^{\text {th }}$ FECAVA Eurocongres, $6^{\text {th }}$ TSAVA Congress, „Modern Veterinary Practices“; 7 -10 September, Istanbul, Turkey, p. 457.

ELLIS, W. A. (2010): Control of canine leptospirosis in Europe: time for a change? Vet. Rec. 167, 602-605.

DOI: $10.1136 /$ vr.c4965.

FAINE, S., B. ADLER, C. BOLIN, P. PEROLAT (2000): Leptospira and Leptospirosis. $2^{\text {nd }}$ ed. Medisci Press, Melbourne, Australia.

GEISEN, V., C. STENGEL, S. BREM, W. MULLER, C. GREENE, K. HARTMANN (2007): Canine leptospirosis infections - clinical signs and outcome with different suspected Leptospira serogroups (42 cases). J. Small Anim. Pract. 48, 324-328.

DOI: $10.1111 / \mathrm{j} .1748-5827.2007 .00324 . \mathrm{x}$

JANSEN, A., I. SCHONEBERG, C. FRANK, K. ALPERS, T. SCHNEIDER, K. STARK (2005): Leptospirosis in Germany, 1962-2003. Emerg. Infect. Dis. 11, 1048-1054.

DOI: $10.3201 /$ eid1107.041172

KAHN, C., S. M. LINE (2005): Leptospirosis in dogs. In: The Merck Veterinary Manual. $9^{\text {th }}$ edx. Whitehouse Station, N. J., USA: Merck \& Co., INC. 525-529.

KLAASEN, H. L., M. J. MOLKENBOER, M. P. VRIJENHOEK, M. J. KAASHOEK (2003): Duration of immunity in dogs vaccinated against leptospirosis with a bivalent inactivated vaccine. Vet. Microbiol. 95, 121-132.

DOI: $10.1016 / \mathrm{s} 0378-1135(03) 00152-4$

KLAASEN, H., B. ADLER (2015): Recent advances in canine leptospirosis: focus on vaccine development. Veterinary Medicine: Research and Reports. 6, 245-260.

DOI: $10.2147 /$ VMRR.S59521 
KO, A. I., M. GALVAO REIS, C. M. RIBEIRO DOURADO, W. D. JOHNSON, L. W. RILEY (1999): Urban epidemic of severe leptospirosis in Brazil. Salvador Leptospirosis Study Group. Lancet. 354, 820-825.

DOI: $10.1016 / \mathrm{s} 0140-6736(99) 80012-9$

MAJOR, A., A. SCHWEIGHAUSER, T. FRANCEY (2014): Increasing incidence of canine leptospirosis in Switzerland. Int. J. Environ. Res. Pub. He. 11,

DOI: 7242-7260. 10.3390/ijerph110707242

MARIĆ, J., M. ELEZOVIĆ, D. VOJINOVIĆ, M. MILOVANOVIĆ, I. ZARIĆ, B. ĐURIČIĆ (2012): Investigation of the presence of different leptospira serotypes in hunting dog population in Western Serbia. International Symposium of Hunting, "Contemporary Aspects of Sustainable Management of Game Populations”, 22-24 June, Zemun-Belgrade, Serbia, pp. 137-139 (in Serbian).

MOORE, G. E., L. F. GUPTILL, N. W. GLICKMAN, R. J. CALDANARO, D. AUCOIN, L. T. GLICKMAN (2006): Canine leptospirosis, United States, 2002-2004. Emerg. Infect. Dis. 12, 501-503.

DOI: $10.3201 /$ eid1205.050809

OŽEGOVIĆ, T. (1992): Investigation of the prevalence of leptospirosis in dogs in Sarajevo and surroundings. PhD Thesis. University of Sarajevo, Veterinary Faculty, Sarajevo, Bosnia and Hercegovina, p. 84 (in Bosnian).

RADOJIČIĆ, S., M. VALČIĆ, B. ĐURIČIĆ (2011): Infectious Diseases of Animals, Special Section, Naučna KMD, Belgrade, Serbia, p. 664 (in Serbian).

RIBOTTA, M., M. FORTIN, R. HIGGINS, S. BEAUDIN (2000): Canine leptospirosis: serology. Can. Vet. J. 41, 494-495.

SCANZIANI, E., F. ORIGGI, A. M. GIUSTI, G. IACCHIA, A. VASINO, G. PIROVANO, P. SCARPA, S. TAGLIABUE (2002): Serological survey of leptospiral infection in kennelled dogs in Italy. J. Small Anim. Pract. 43, 154-157.

DOI: 10.1111/j.1748-5827.2002.tb00048.x

STOYANOVA, N. TOKAREVICH, L. GRACHEVA, G. VOLKOVA, N. GRACHEVA, S. KRAVCHENKO, N. KUZINA, T. LISEEVA, E. MATSIEVSKAYA, V. PYANUKH, V. SNEGIRIOV, V. SOSNITSKY (2004): Leptospirosis in North-West Russia. Saint-Petersburg Pasteur Institute and State Centre for Sanitary and Epidemiological Surveillance in SaintPetersburg, Arkhangelsk, Murmansk, Novgorod, Pskov, and Republic of Karelia, Russia. 5, 2, 29-32.

SYKES, J. E., K. HARTMANN, K. F. LUNN, G. E. MOORE, R. A. STODDARD, R. E. GOLDSTEIN (2011): 2010 ACVIM small animal consensus statement on leptospirosis: diagnosis, epidemiology, treatment, and prevention. J. Vet. Intern. Med. 25, 1-13.

DOI: $10.1111 / j .1939-1676.2010 .0654 . x$ 
ŠTRITOF MAJETIĆ, Z., J. HABUŠ, Z. MIJAS, V. MOJČEC PERKO, V. STAREŠINA, N. TURK (2012): Serological survey of canine leptospirosis in Croatia - the changing epizootiology of the disease. Vet. arhiv 82, 183-191.

VAN DE MAELE, I., A. CLAUS, F. HAESEBROUCK, S. DAMINET (2008): Leptospirosis in dogs: a review with emphasis on clinical aspects. Vet. Rec. 163, 409-413.

DOI: $10.1136 /$ vr.163.14.409

VENGUŠT, G., R. LINDTNER-KNIFIC, D. ŽELE, A. BIDOVEC (2008): A Leptospira antibodies in wild boars (Sus scrofa) in Slovenia. Eur. J. Wildlife Res. 54, 749.

DOI: $10.1007 / \mathrm{s} 110344-008-0178-7$

Received: 19 June 2018

Accepted: 11 June 2019

\begin{abstract}
LINDTNER KNIFIC, R., A. ĆUTUK, G. GREGURIĆ GRAČNER, A. DOVČ: Seroprevalencija leptospiroze u različitih kategorija pasa u Bosni i Hercegovini. Vet. arhiv 89, 627-640, 2019.

\section{SAŽETAK}

Porast broja pasa lutalica i nepostojanje podataka o prevalenciji leptospiroze u različitih kategorija pasa na području Bosne i Hercegovine bili su glavni razlozi za provedbu ovog istraživanja. Analizirano je ukupno 300 uzoraka seruma iz tri kategorije pasa različitih pasmina iz 12 gradova. U mikroskopskom aglutinacijskom testu (MAT) upotrijebljeno je 12 serovarova leptospira, a za njih osam je potvrđena prisutnost specifičnih protutijela. Udio seropozitivnih pasa bio je 22,3 \% (67 od 300). Najveća seropozitivnost ( $\mathrm{n}=38 ; 42,7 \%)$ utvrđena je za serovar Pomona. Seropozitivnost za ostale serovarove bila je: Canicola (14,6 \%), Icterohaemorrhagiae (13,5\%), Sejroe (12,4\%), Autumnalis (12,4 \%), Grippotyphosa (2,2 \%), Bratislava (1,1 \%) i Australis $(1,1 \%)$. Najveći broj pozitivnih nalaza bio je kod razrjeđenja seruma $1: 100(39,3 \%, \mathrm{n}=35)$. Najveći broj pozitivnih reakcija dokazan je u kućnih pasa $(29,3 \%, 29$ od 99), a zatim u pasa lutalica $(21,6 \%, 24$ od 111), dok je najmanji broj pozitivnih reakcija zabilježen u lovačkih i pasa čuvara $(15,6 \%, 14$ od 90$)$. Cijepljenje tetravalentnim cjepivima koja uključuju serovarove Icterohaemorrhagiae, Canicola, Pomona i Grippotyphosa mogla bi biti učinkovita mjera prevencije leptospiroze u pasa.
\end{abstract}

Ključne riječi: leptospiroza; dijagnostika; mikroskopski aglutinacijski test; serologija; psi; Bosna i Hercegovina 